\title{
Lamb meat quality of two breeds with protected origin designation. Influence of breed, sex and live weight
}

\author{
A. Teixeira ${ }^{a, *}$, S. Batista ${ }^{a}$, R. Delfa ${ }^{b}$, V. Cadavez ${ }^{\text {a }}$ \\ a Escola Superior Agrária, Instituto Politécnico de Bragança, Apartado 172, 5301-855 Bragança, Portugal \\ ${ }^{\mathrm{b}}$ Unidad de Tecnología en Producción Animal, CITA de Aragón, Apto 727, 50080 Zaragoza, Espanha
}

Received 14 April 2005; received in revised form 28 April 2005; accepted 28 April 2005

\begin{abstract}
Lamb meat quality of two Portuguese products was examined. The influences of slaughter weight, sex and breed on eating quality were evaluated. Data were obtained from 72 lambs of two different breeds with protected designation origin. In accord with the normal slaughter weight in the region three classes were considered: A: 9-14 kg live weight; B: 14-19 kg live weight and C: $19-$ $24 \mathrm{~kg}$ live weight. $\mathrm{pH}$ of $M$. longissimus thoracis et lumborum muscle (MTL) was measured $1 \mathrm{~h}$ and $24 \mathrm{~h}$ after slaughter. Meat colour was estimated in the $M$. longissimus thoracis et lumborum muscle (MTL) muscle on the 12 th rib using the $L^{*} a^{*} b^{*}$ system. Shear force was evaluated $72 \mathrm{~h}$ after slaughter. Sensorial analysis was assessed by a trained taste panel of $12 \mathrm{members}$. The pH values found could be considered within the normal $\mathrm{pH}$ range, between 5.5 and 5.9 . When the $\mathrm{pH}$ measurement was made $24 \mathrm{~h}$ after slaughter, the heavy lambs had significant higher value than the light lambs. In relation to colour variables, live weight, sex and breed had no effect on the red index $\left(a^{*}\right)$. Lightness $(L)$ decreased with increasing live weight and the light lambs had higher yellow index $\left(b^{*}\right)$ than the heavier lambs. Shear force increased with live weight and the Bragançano breed had a greater mean shear force than the Mirandesa ( 7.8 vs. $\left.6.8 \mathrm{~kg} / \mathrm{cm}^{2}\right)$. The heavy carcasses had more flavour intensity than the light ones. Mirandesa lambs had significantly lower values for toughness, stringy and odour intensity than Bragançana lambs.
\end{abstract}

(C) 2005 Elsevier Ltd. All rights reserved.

Keywords: Lamb; Meat quality; Instrumental measurement; Sensory analysis

\section{Introduction}

According to Warriss (2000), when most people talk about quality they tend to mean the functional quality that refers to desirable attributes in a product such as yield, technological properties and palatability. We considered yield as the proportion of saleable meat and muscle size and shape, the colour of meat, $\mathrm{pH}$ and shear force as technological properties, and texture and tenderness, juiciness, flavour and odour as palatability characteristics.

\footnotetext{
* Corresponding author. Tel.: +351 273 303203; fax: +351 325405.

E-mail address: Teixeira@ipb.pt (A. Teixeira).
}

The increasing importance of lamb meat quality to butchers and consumers has been an objective of several studies in recent years (Bennett, 1997; Bickerstaffe, Le Couter, \& Morton, 1996; Carlucci, Napolitano, Girolami, \& Monteleone, 1999; Channon, Ross, Cooper, \& Maden, 1993; Devine, Graafhuis, Muir, \& Chrystall, 1993; Ellis, Webster, \& Brown, 1997; Hoffman, Muller, Cloete, \& Schmidt, 2003; Hopkins, 1993; Hopkins, Ferrier, Channon, \& MacDonald, 1995; Purchas, Silva Sobrinho, Garrick, \& Lowe, 2002; Safari, Fogarty, Ferrier, Hopkins, \& Gilmour, 2001; Young, Reid, \& Scales, 1993). More recently, Rødbotten, Kubbeød, Lea, and Ueland (2004) working with different species, including lamb, investigated if meats could be described and compared by sensory analysis. 
Lamb meat quality is influenced by several factors, such as breed (Fisher et al., 1999; Fogarty, Hopkins, \& Vande Ven, 2000; Hoffman et al., 2003; Purchas et al., 2002; Safari et al., 2001; Sañudo et al., 1997; Santos Silva, Mendes, \& Bessa, 2002) slaughter weight (Jeremiah, Tong, \& Gibson, 1998; Purchas et al., 2002; Sañudo, Santolaria, María, Osorio, \& Sierra, 1996) and sex (Butler-Hogg, Francombe, \& Dransfield, 1984; Dransfield, Nute, Hogg, \& Walters, 1990). Nevertheless other factors could influence meat quality such as pre-slaughter stress, carcass cooling rate and ageing regimen.

The implementation of provisions of Council Regulation (EEC) No. 2081/92 of 14 July, 1992 on the protection of geographical indications and designations of origin for agricultural products and Council Regulation (EEC) No. 2082/92 on certificates of specific character for agricultural products and foodstuffs was a great incentive for small ruminant production in several countries particularly in the NE of Portugal that has a great tradition in lamb production. Producers were encouraged to continue producing according to the traditional methods because the products are well accepted by the consumers. In consequence, more and more information, such as quality and safety guarantee is required by consumers.

This work examines the sensory quality of meat of two Portuguese breeds with protected origin designation, representing the type commonly slaughtered in the Mediterranean area, particularly in Portugal. The influence of slaughter weight, sex and breed on some characteristics of the lamb and eating quality were also evaluated.

\section{Material and methods}

\subsection{Animals and sampling}

Data were obtained from 72 lambs (18 lambs from each sex and breed were used) from two different breeds selected at random by each of the two National Association of Breed Producers, and reared under normal conditions and according to the main elements of the specifications for these protected designation origin products. Lambs remain with their mothers during grazing. There are extensive areas of hill grazing at an altitude varying from 481 to $1000 \mathrm{~m}$, in a succession of uplands and deep valleys the weather is often harsh and there are wide variations in food supply. The flocks are rarely given supplementary foods, only during winter some meadow hay is given. Lambs were raised traditionally, suckling milk from their dams, not being weaned until slaughter at 3-4 months of age, normally at the end of autumn.

According to the normal slaughter weights in the region, three classes were considered: A: for live weight be- tween 9 and $14 \mathrm{~kg}$; B: for live weight between 14 and $19 \mathrm{~kg}$ and $\mathbf{C}$ : for live weight between 19 and $24 \mathrm{~kg}$.

Lambs were transported in an appropriate manner under the animal welfare rules and according to UE government regulations. From the origin to slaughter house the Mirandesa lambs travelled $50 \mathrm{~km}$ further than the Bragançana lambs.

All lambs were slaughtered after a $24 \mathrm{~h}$ fast in the experimental slaughter house at the Bragança's School of Agriculture (Escola Superior Agrária de Bragança). After slaughter, carcasses were cooled at $4{ }^{\circ} \mathrm{C}$ for $24 \mathrm{~h}$. Carcasses were halved carefully. The kidney and pelvic fat were removed and weighed. The left side of each carcass was divided into eight standardized commercial joints: leg, chump, loin, ribs, anterior ribs, shoulder, breast and neck. The joint procedure was outlined by Teixeira (1984) according to the Zootechnique National Station cut (Estação Zootécnica Nacional - EZN cut) Calheiros and Neves (1968). Each joint was then dissected into muscle, subcutaneous fat, intermuscular fat, bone and remainder (major blood vessels, ligaments, tendons and thick connective tissue sheets associated with muscles). In total 72 carcasses were evaluated and completely dissected.

\subsection{Instrumental measurement}

All instrumental measurements were obtained from the left side of the carcass. M. longissimus thoracis et lumborum muscle (MTL) $\mathrm{pH}$ was measured $1 \mathrm{~h}$ and $24 \mathrm{~h}$ after slaughter on the 12th rib using the equipment Crison, pH-metro 507 and a 52-32 spear electrode. Meat colour was estimated in the MTL muscle on the 12th rib using the $L^{*} a^{*} b^{*}$ system with a chromameter Minolta CR 300. This system of colour was described with the coordinates $L^{*} a^{*} b^{*}$ representing lightness, redness and yellowness (CIE, 1986). Colour measurements were made on freshly cut surfaces in seconds after carcasses have been cooled at $4{ }^{\circ} \mathrm{C}$ for $24 \mathrm{~h}$. Shear force was evaluated $72 \mathrm{~h}$ after slaughter, using an INSTRON 5543-J 3177 equipped with a Warner-Bratzler device. MTL muscles were cooked within plastic bags in a $70{ }^{\circ} \mathrm{C}$ water bath for $90 \mathrm{~min}$. Half an hour after, muscle sub-samples $\left(1 \mathrm{~cm}^{2}\right.$ cross-section) were taken from each MTL muscle for shear force evaluation. For each animal eight shears were made. The measurement was recorded as the average yield force in kilograms, required to shear perpendicularly to the direction of the fibres.

\subsection{Sensory analysis}

The lumbar region of the longissimus thoracis et lumborum muscle from the right side of the carcass was taken for sensory analysis by a trained taste panel of 12 members. Panel members were selected and trained in 
accordance with the Portuguese guidelines (NP ISO $8586-1$, 2001). Samples aged for $72 \mathrm{~h}$ were vacuum packed and frozen at $-21^{\circ} \mathrm{C}$ until taste panel evaluation. The day before the panel sensory session, samples were thawed at $4{ }^{\circ} \mathrm{C}$. Samples were wrapped individually in cooking bags and roasted in an oven until the internal muscle temperature reached between 70 and $80^{\circ} \mathrm{C}$.

Immediately after cooking the MTL muscle was divided in $2 \times 2 \mathrm{~cm}$ cubed samples and wrapped in aluminium foil, marked with random three-digit cods and placed in a preheated oven of $60-70{ }^{\circ} \mathrm{C}$ and evaluated within $10 \mathrm{~min}$. The panel members were seated in individual randomised booths in a temperature and light controlled room. In all sessions the room temperature was between 20 and $22{ }^{\circ} \mathrm{C}$ with $60-70 \%$ humidity and the booths illuminated with red light.

After training, panellists were asked to assess each sample for the following sensory attributes: odour intensity (odour associated with raw meat, animal species or cooked lamb meat), toughness (the force needed to chew), juiciness (water perceived during mastication), flavour intensity (flavour of raw meat, associated with the animal species or cooked lamb meat), stringy (fibres perceived during the mastication), sweet intensity (flavour of sugar) and overall acceptability, using a nonstructured $1-10 \mathrm{~cm}$ scales, representing at the extremes the minimum $(0-$ absence of the sensation $)$ and the maximum (10 - sensation extremely intense).
The sensorial evaluation consisted of six sessions. In each session, panellists assessed all samples corresponding to 12 treatments. Samples were presented randomly in each session. A total of 60 samples were tasted by each of the panellists.

\subsection{Statistical analysis}

The experimental design consisted of balanced incomplete blocks and the treatment design was a $2 \times 3 \times 2$ factorial with two sexes, three carcass weight and two breeds as factors. Data were analysed using the Mixed Models Procedure by SAS version 9.1 (SAS, 2004).

\section{Results and discussion}

\subsection{General results}

The means, standard deviation, maximum and minimum of the live weight, carcass components, instrumental measurements and sensory quality characteristics are shown in Table 1. All characteristics have a substantial variation suggesting that a great range of live weight and carcass fat depots representative of Bragançano and Mirandesa lamb carcasses normally slaughtered commercially. Toughness, juiciness and

Table 1

Means, maximum, minimum and coefficient of variation $(\mathrm{CV})$ of the live weight, carcass components, instrumental measurements and sensory quality characteristics of two lamb breeds

\begin{tabular}{|c|c|c|c|c|}
\hline$\underline{\text { Variables }}$ & Mean & Maximum & Minimum & $\mathrm{CV}(\%)$ \\
\hline Live weight (kg) & 16.04 & 22.30 & 9.80 & 26.66 \\
\hline \multicolumn{5}{|l|}{ Carcass components } \\
\hline Muscle (kg) & 2.25 & 4.04 & 1.10 & 31.47 \\
\hline Subcutaneous fat (kg) & 0.23 & 0.65 & 0.03 & 65.07 \\
\hline Intermuscular fat (kg) & 0.37 & 0.93 & 0.07 & 51.25 \\
\hline Kidney and pelvic fat $(\mathrm{kg})$ & 0.16 & 0.69 & 0.01 & 90.05 \\
\hline Bone (kg) & 0.75 & 1.27 & 0.42 & 26.41 \\
\hline Total carcass fat $(\mathrm{kg})$ & 0.77 & 2.18 & 0.12 & 60.85 \\
\hline \multicolumn{5}{|l|}{ Instrumental measurements } \\
\hline $\mathrm{pH} 1$ & 6.2 & 6.8 & 5.5 & 4.7 \\
\hline pH 24 & 5.7 & 5.9 & 5.5 & 2.1 \\
\hline$L^{*}$ & 41.5 & 53.2 & 34.1 & 8.5 \\
\hline$a^{*}$ & 16.5 & 21.5 & 11.5 & 13.7 \\
\hline$b^{*}$ & 9.5 & 12.5 & 6.5 & 15.2 \\
\hline Shear force $\left(\mathrm{kg} / \mathrm{cm}^{2}\right)$ & 7.3 & 11.6 & 3.0 & 28.0 \\
\hline \multicolumn{5}{|l|}{ Sensory characteristics } \\
\hline Toughness & 3.4 & 7.1 & 0.7 & 47.7 \\
\hline Juiciness & 3.4 & 6.3 & 1.4 & 35.1 \\
\hline Odour intensity & 5.0 & 6.7 & 3.5 & 15.7 \\
\hline Flavour intensity & 4.3 & 6.7 & 2.4 & 17.1 \\
\hline Overall acceptability & 3.6 & 5.8 & 1.7 & 25.6 \\
\hline Stringy & 3.1 & 5.8 & 0.6 & 40.8 \\
\hline Sweet intensity & 3.0 & 4.1 & 1.4 & 16.9 \\
\hline
\end{tabular}


stringiness were the characteristics with highest range of variation, suggesting the subjectivity of these characteristics, but also reflecting the high variation in shear force that was an objective measurement. The values of the coefficient of variation for the components of carcass and sensory characters show that the products were very variable, reflecting the wide range of slaughter weights permitted for these protected designation origin products.

\subsection{Instrumental measurements}

In Table 2 the effects of live weight, sex and breed on instrumental measurements are presented. The $\mathrm{pH}$ values particularly the values obtained $24 \mathrm{~h}$ after slaughter, could be considered, according to Devine et al. (1993), within the normal $\mathrm{pH}$ range assuming that an ultimate $\mathrm{pH}$ value greater than 5.8 is regarded as undesirable. Our results are similar to the findings of Safari et al. (2001) and Hoffman et al. (2003). Live weight had no effect on $\mathrm{pH}$ measured $1 \mathrm{~h}$ after slaughter, but when the measurement was made $24 \mathrm{~h}$ after slaughter the heavy lambs had significantly higher $\mathrm{pH}$ values. Sañudo et al. (1996) and Beriain et al. (2000), working with lambs from Spanish breeds also observed higher $\mathrm{pH}$ values on the heavy carcasses but Vergara, Molina, and Gallego (1999) also working with a Spanish breed did not find effects of slaughter weight on $24 \mathrm{~h} \mathrm{pH}$. In the present work, no differences were found between breeds for $\mathrm{pH}$ measured $24 \mathrm{~h}$ after slaughter, but when $\mathrm{pH}$ was measured $1 \mathrm{~h}$ after slaughter the Mirandesa breed had significantly higher values. This difference between breeds could be attributed to the stress caused by the transport that the lambs of Mirandesa breed were submitted to between the farm and the slaughter house. Sex had no effect on the $24 \mathrm{~h} \mathrm{pH}$, but when $\mathrm{pH}$ was measured $1 \mathrm{~h}$ after slaughter, we verified a small tendency for males to have a higher $\mathrm{pH}$ in accord with the results of Vergara and Gallego (1999) and Fogarty et al. (2000). The significant interaction between live weight and sex could result from the small value found for lightest female lambs compared with the fattest male lambs of the Mirandesa breed, 5.8 and 5.6, respectively.

In relation to colour variables live weight, sex and breed had no effect on the red index $\left(a^{*}\right)$. Lightness $(L)$ decreased with the increasing live weight and the light lambs had a higher yellow index $\left(b^{*}\right)$ than the others. This effect of live weight on colour instrumental measurements was also found by Sañudo et al. (1996); Vergara et al. (1999); Beriain et al. (2000) and Fogarty et al. (2000). The effect of live weight on $a^{*}$ was also reported by Dransfield et al. (1990) but according Sanudo et al. (1997) the light lambs traditionally consumed in the Mediterranean area have lower yellow index probably due to the milk diet of low-iron content received by the suckling lambs. In agreement with our results Santos Silva et al. (2002) working with Portuguese Merino, found an effect of slaughter weight on the $L$ and $a^{*}$. In our work, breed only affected the yellow index and the Bragançano lambs had higher values than the Mirandesa lambs. The effect of breed on this

Table 2

Effects of live weight, sex and breed on the instrumental measurements

\begin{tabular}{|c|c|c|c|c|c|c|c|}
\hline & $\mathrm{N}$ & pH 1 & $\mathrm{pH} 24$ & $L^{*}$ & $a^{*}$ & $b^{*}$ & Shear force $\left(\mathrm{kg} / \mathrm{cm}^{2}\right)$ \\
\hline $\begin{array}{l}\text { Live weight } \\
\text { A: } 9<P 1<14 \mathrm{~kg} \\
\text { B: } 14<P 2<19 \mathrm{~kg} \\
\text { C: } 19<P 3<24 \mathrm{~kg}\end{array}$ & $\begin{array}{l}24 \\
24 \\
24\end{array}$ & $\begin{array}{l}6.2 \pm 0.05^{\mathrm{a}} \\
6.3 \pm 0.06^{\mathrm{a}} \\
6.2 \pm 0.05^{\mathrm{a}}\end{array}$ & $\begin{array}{l}5.7 \pm 0.02^{\mathrm{b}} \\
5.7 \pm 0.02^{\mathrm{b}} \\
5.8 \pm 0.02^{\mathrm{a}}\end{array}$ & $\begin{array}{l}44.0 \pm 0.55^{\mathrm{a}} \\
41.4 \pm 0.56^{\mathrm{b}} \\
39.0 \pm 0.54^{\mathrm{c}}\end{array}$ & $\begin{array}{l}15.9 \pm 0.43^{\mathrm{a}} \\
16.5 \pm 0.44^{\mathrm{a}} \\
17.0 \pm 0.43^{\mathrm{a}}\end{array}$ & $\begin{array}{l}10.3 \pm 0.26^{\mathrm{a}} \\
4.2 \pm 0.27^{\mathrm{b}} \\
8.8 \pm 0.26^{\mathrm{b}}\end{array}$ & $\begin{array}{l}6.1 \pm 0.32^{\mathrm{c}} \\
7.2 \pm 0.32^{\mathrm{b}} \\
8.7 \pm 0.31^{\mathrm{a}}\end{array}$ \\
\hline $\begin{array}{l}\text { Sex } \\
\text { Males } \\
\text { Females }\end{array}$ & $\begin{array}{l}36 \\
36\end{array}$ & $\begin{array}{l}6.3 \pm 0.04^{\mathrm{a}} \\
6.2 \pm 0.04^{\mathrm{a}}\end{array}$ & $\begin{array}{l}5.7 \pm 0.02^{\mathrm{a}} \\
5.7 \pm 0.02^{\mathrm{a}}\end{array}$ & $\begin{array}{l}42.2 \pm 0.45^{\mathrm{a}} \\
40.7 \pm 0.45^{\mathrm{b}}\end{array}$ & $\begin{array}{l}16.1 \pm 0.35^{\mathrm{a}} \\
16.9 \pm 0.36^{\mathrm{a}}\end{array}$ & $\begin{array}{l}9.6 \pm 0.21^{\mathrm{a}} \\
9.3 \pm 0.27^{\mathrm{a}}\end{array}$ & $\begin{array}{l}7.2 \pm 0.26^{\mathrm{a}} \\
7.5 \pm 0.26^{\mathrm{a}}\end{array}$ \\
\hline $\begin{array}{l}\text { Breed } \\
\text { Bragançana } \\
\text { Mirandesa }\end{array}$ & $\begin{array}{l}36 \\
36\end{array}$ & $\begin{array}{l}6.1 \pm 0.04^{\mathrm{b}} \\
6.4 \pm 0.04^{\mathrm{a}}\end{array}$ & $\begin{array}{l}5.7 \pm 0.02^{\mathrm{a}} \\
5.7 \pm 0.02^{\mathrm{a}}\end{array}$ & $\begin{array}{l}41.3 \pm 0.45^{\mathrm{a}} \\
41.6 \pm 0.45^{\mathrm{a}}\end{array}$ & $\begin{array}{l}16.8 \pm 0.36^{\mathrm{a}} \\
16.2 \pm 0.35^{\mathrm{a}}\end{array}$ & $\begin{array}{l}9.8 \pm 0.21^{\mathrm{a}} \\
9.1 \pm 0.21^{\mathrm{b}}\end{array}$ & $\begin{array}{l}7.8 \pm 0.26^{\mathrm{a}} \\
6.8 \pm 0.26^{\mathrm{b}}\end{array}$ \\
\hline $\begin{array}{l}\text { Effects } \\
\text { Live weight } \\
\text { Sex } \\
\text { Breed }\end{array}$ & & $\begin{array}{l}\text { NS } \\
\text { NS } \\
* * *\end{array}$ & $\begin{array}{l}* * \\
\text { NS } \\
\text { NS }\end{array}$ & $\begin{array}{l}* * * \\
* \\
\text { NS }\end{array}$ & $\begin{array}{l}\text { NS } \\
\text { NS } \\
\text { NS }\end{array}$ & $\begin{array}{l}* * * \\
\text { NS } \\
*\end{array}$ & $\begin{array}{l}* * * \\
\text { NS } \\
* *\end{array}$ \\
\hline $\begin{array}{l}\text { Interactions } \\
\text { Live weight } \times \text { sex } \\
\text { Live weight } \times \text { breed } \\
\text { Sex } \times \text { breed } \\
\text { Live weight } \times \text { sex } \times \text { breed }\end{array}$ & & $\begin{array}{l}\text { NS } \\
\text { NS } \\
\text { NS } \\
\text { NS }\end{array}$ & $\begin{array}{l}\mathrm{NS} \\
* * \\
\mathrm{NS} \\
\mathrm{NS}\end{array}$ & $\begin{array}{l}\text { NS } \\
* * \\
\text { NS } \\
\text { NS }\end{array}$ & $\begin{array}{l}* \\
\text { NS } \\
\text { NS } \\
\text { NS }\end{array}$ & $\begin{array}{l}\text { NS } \\
\text { NS } \\
\text { NS } \\
\text { NS }\end{array}$ & $\begin{array}{l}\text { NS } \\
* * * \\
\text { NS } \\
\text { NS }\end{array}$ \\
\hline
\end{tabular}

${ }^{*} P \leqslant 0.05 ;{ }^{* *} P \leqslant 0.01 ; * * * P \geqslant 0.001$. NS: Not significant; values in the same column followed by the same letter are not significantly different $(P \geqslant 0.05)$. 
colour parameter was also found by Fogarty et al. (2000) and Sañudo et al. (1997). Sex only affected the lightness, with males having significantly higher values than the females. The interaction between live weight and breed was probably a result of the lighter weight of the Mirandesa lambs in the heavy live weight range C $(19<P 3<24 \mathrm{~kg})$. The interaction between live weight and sex for redness (a) was the result of differences between males and females within the live weight groups $\mathbf{B}$ and $\mathbf{C}$; males having higher values than females (17.6 vs. 16.4).

Shear force increased with live weight. The values found were similar to those found by Sañudo et al. (1996); Beriain et al. (2000) and Hoffman et al. (2003). The lowest values found for the lightest lambs were also found by Schönfeldt, Naudé, Bok, Van Heerden, and Sowden (1993) for young lambs and kids. There was a significant difference between breeds, Bragançano lambs had higher shear force values than Mirandesa lambs. Hoffman et al. (2003) found an influence of breed on shear value but Sañudo et al. (1997); Hopkins and Fogarty (1998); Safari et al. (2001) and Purchas et al. (2002) found no differences. There were no significant differences between sex and a significant interaction between live weight and sex was found, mainly due to the low values found for the Mirandesa light lambs when compared with the other live weight groups of the Bragançano lambs.

\subsection{Sensory quality}

In Table 3, the effects of live weight, sex and breed on the sensorial quality characteristics are presented. Live weight at slaughter only affected the flavour intensity. The heavy carcasses had more flavour intensity than the light ones. This has also been reported by Crouse, Busboom, Field, and Ferrel (1981); Butler-Hogg et al. (1984) and Jeremiah et al. (1998). However Sañudo et al. (1996), working with lambs of the Aragonesa breed designated as "Ternasco de Aragón", which was the first Spanish fresh meat with denomination of origin did not find effects of slaughter weight on flavour. None of the sensory assessments were affected by sex (Vergara et al. (1999) and Vergara \& Gallego (1999)), working with Spanish light and medium weight lambs also found no effects of sex on sensory assessments. Mirandesa lambs had significantly lower values for toughness, stringiness and odour intensity than Bragançana lambs. Taking into account that, according to (Safari et al., 2001), tenderness, flavour and juiciness are the most important sensory attributes in overall acceptability, the MTL muscle of Mirandesa lambs was more acceptable than the MTL muscle of Bragançano lambs. These differences are illustrated in Fig. 1 by a plot of sensory evaluation characteristics for the two studied breeds. The difference between breeds for shear force corresponded to the difference in toughness. This relationship between shear force and tenderness was also identified by Safari et al.

Table 3

Effects of live weight, sex and breed on the sensory quality characteristics

\begin{tabular}{|c|c|c|c|c|c|c|c|}
\hline & Toughness & Juiciness & Odour intensity & Flavour intensity $^{\mathrm{A}}$ & Overall acceptability & Stringy & Sweet intensity \\
\hline \multicolumn{8}{|l|}{ Live weight } \\
\hline A: $9<P 1<14 \mathrm{~kg}$ & $3.1 \pm 0.29^{\mathrm{a}}$ & $3.0 \pm 0.24^{\mathrm{a}}$ & $4.8 \pm 0.15^{\mathrm{a}}$ & $4.0 \pm 0.14^{\mathrm{a}}$ & $3.3 \pm 0.17^{\mathrm{a}}$ & $3.0 \pm 0.23^{\mathrm{a}}$ & $2.9 \pm 0.10^{\mathrm{a}}$ \\
\hline B: $14<P 2<19 \mathrm{~kg}$ & $3.5 \pm 0.29^{\mathrm{a}}$ & $3.5 \pm 0.24^{\mathrm{a}}$ & $5.2 \pm 0.16^{\mathrm{a}}$ & $4.5 \pm 0.15^{\mathrm{a}, \mathrm{b}}$ & $3.7 \pm 0.18^{\mathrm{a}}$ & $3.0 \pm 0.23^{\mathrm{a}}$ & $3.1 \pm 0.11^{\mathrm{a}}$ \\
\hline C: $19<P 3<24 \mathrm{~kg}$ & $3.8 \pm 0.28^{\mathrm{a}}$ & $3.8 \pm 0.23^{\mathrm{a}}$ & $4.9 \pm 0.15^{\mathrm{a}}$ & $4.5 \pm 0.14^{\mathrm{b}}$ & $3.6 \pm 0.17^{\mathrm{a}}$ & $3.4 \pm 0.22^{\mathrm{a}}$ & $3.0 \pm 0.10^{\mathrm{a}}$ \\
\hline \multicolumn{8}{|l|}{ Sex } \\
\hline Males & $3.4 \pm 0.23^{\mathrm{a}}$ & $3.7 \pm 0.19^{\mathrm{a}}$ & $4.8 \pm 0.12^{\mathrm{a}}$ & $4.2 \pm 0.12^{\mathrm{a}}$ & $3.7 \pm 0.14^{\mathrm{a}}$ & $3.1 \pm 0.18^{\mathrm{a}}$ & $3.0 \pm 0.08^{\mathrm{a}}$ \\
\hline Females & $3.5 \pm 0.23^{\mathrm{a}}$ & $3.2 \pm 0.20^{\mathrm{a}}$ & $5.1 \pm 0.12^{\mathrm{a}}$ & $4.5 \pm 0.12^{\mathrm{a}}$ & $3.4 \pm 0.14^{\mathrm{a}}$ & $3.2 \pm 0.18^{\mathrm{a}}$ & $3.0 \pm 0.08^{\mathrm{a}}$ \\
\hline \multicolumn{8}{|l|}{ Breed } \\
\hline Bragançana & $4.1 \pm 0.23^{\mathrm{a}}$ & $3.4 \pm 0.20^{\mathrm{a}}$ & $5.1 \pm 0.12^{\mathrm{a}}$ & $4.5 \pm 0.12^{\mathrm{a}}$ & $3.4 \pm 0.14^{\mathrm{a}}$ & $3.6 \pm 0.19^{\mathrm{a}}$ & $3.0 \pm 0.08^{\mathrm{a}}$ \\
\hline Mirandesa & $2.8 \pm 0.23^{\mathrm{b}}$ & $3.4 \pm 0.19^{\mathrm{a}}$ & $4.8 \pm 0.12^{\mathrm{b}}$ & $4.2 \pm 0.12^{\mathrm{a}}$ & $3.7 \pm 0.14^{\mathrm{a}}$ & $2.6 \pm 0.18^{\mathrm{b}}$ & $2.9 \pm 0.08^{\mathrm{a}}$ \\
\hline \multicolumn{8}{|l|}{ Effects } \\
\hline Live weight & NS & NS & NS & $*$ & NS & NS & NS \\
\hline Sex & NS & NS & NS & NS & NS & NS & NS \\
\hline Breed & $* * *$ & NS & $*$ & NS & NS & $* * *$ & NS \\
\hline \multicolumn{8}{|l|}{ Interactions } \\
\hline Live weight $\times$ sex & NS & NS & NS & NS & NS & NS & NS \\
\hline Live weight $\times$ breed & $* *$ & NS & NS & NS & NS & $* *$ & NS \\
\hline Sex $\times$ breed & NS & NS & NS & NS & NS & NS & NS \\
\hline Live weight $\times \operatorname{sex} \times$ breed & NS & NS & NS & NS & NS & NS & NS \\
\hline
\end{tabular}

$* P \leqslant 0.05, * * P \leqslant 0.01 ; * * * P \leqslant 0.05$. NS: Not significant; values followed by the same letter are not significantly different $(P \geqslant 0.059)$.

A For statistic analysis this variable was normalized by the "box cox y transformation" (F2-1)/8.48 procedure recommended by statistical SAS programme. Nevertheless, the means and standard deviation presented correspond to the observed values. 


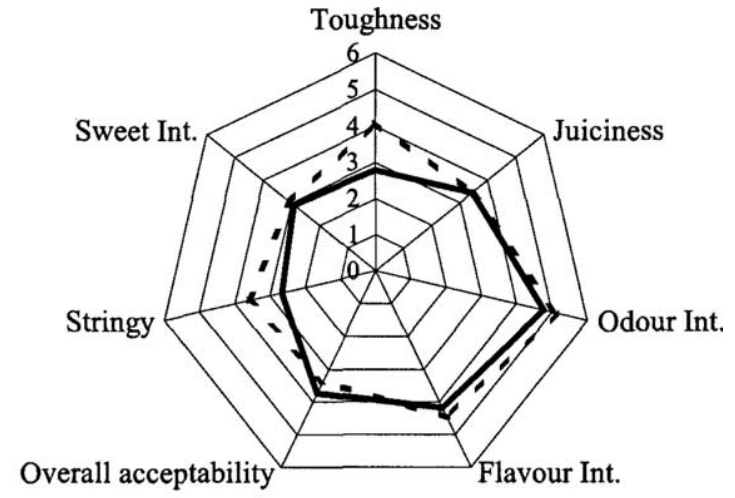

\section{Mirandesa Breed - - - Bragançana Breed}

Fig. 1. Plot of sensory evaluation characteristics for the two studied breeds.

(2001). Differences between breeds were also found by Sañudo et al. (1997) working with lambs from some Spanish breeds and the Awassi breed, and Fisher et al. (1999) working with some UK breeds, and Jeremiah et al. (1998) working with lambs of several breeds currently marketed in Canada. No effects on flavour were found for live weight at slaughter, breeds and sex. This agrees with Crouse et al. (1981) and Crouse, Ferrell, Field, Busboom, and Miller (1982) and Jeremiah et al. (1998).

Sweet intensity was not affected by live weight, breed, or sex.

\section{Conclusion}

The aim of this study was to evaluate lamb meat quality of two Portuguese breeds with protected origin designation, representing the consumer type slaughtered in the Mediterranean area, particularly in Portugal. The results showed that lamb meat quality was variable, probably reflecting the wide range of carcass weights allowed for these protected designation origin products No breed differences were found between breeds for $\mathrm{pH}$ measured $24 \mathrm{~h}$ after slaughter. An effect of live weight on colour instrumental measurements was found; lightness $(L)$ decreased with increasing live weight and the light lambs had a higher yellow index $\left(b^{*}\right)$ than the others. Breed affected only the yellow index and the Bragançano lambs had higher values than Mirandesa lambs. Sex only affected the lightness; males having higher values than the females. Shear force increased with live weight and the MTL of Bragançano lambs had higher shear force values than that of the Mirandesa lambs. The MTL of Mirandesa lambs had significantly lower values for toughness, stringiness and odour intensity than Bragançana lambs. The MTL of Mirandesa lambs was more acceptable than that of the Bragançano lambs.

\section{References}

Bennett, J. M. (1997). Eating quality of lamb. Background paper. Sydney, Australia: Meat Research Corporation, 16pp.

Beriain, M., Horcada, A., Purroy, A., Lizado, G., Chasco, J., \& Mendizabal, J. (2000). Characteristics of Lacha and Rasa Aragonesa lambs slaughtered at three live weights. Journal of Animal Science, 78, 3070-3077.

Bickerstaffe, R., Le Couter, C. E., \& Morton, J. D. (1996). Variation in the tenderness of meat available to consumers. Proceeding of the Nutrition Society of New Zealand, 21, 125-129.

Butler-Hogg, B. W., Francombe, M. A., \& Dransfield, E. (1984). Carcass and meat quality of ram and ewe lambs. Animal Production, 39, 107-113.

Calheiros, F., \& Neves, A. (1968). Rendimentos ponderais no cordeiro Merino Precoce. Carcaça e $5^{\circ}$ quarto. Sep. Boletim Pecuário, XXXVI, 117-126.

Carlucci, A., Napolitano, F., Girolami, A., \& Monteleone, E. (1999). Methodological approach to evaluate the effects of age at slaughter and storage temperature and time on sensory profile lamb meat. Meat Science, 52, 391-395.

Channon, H. A., Ross, I. S., Cooper, K. L., Maden, J. J. L. (1993). Quality assurance program for lamb: monitoring meat quality of Elite lamb carcasses. Proceeding of Australian Meat Industry Research Conference, Meat, 93, Queensland.

CIE (1986). Colorimetry (2nd ed.). CIE Publications No. 15.2. Commission Internationale de l'Eclairage: Vienna.

Council Regulation (EEC) No. 2081/92 of 14 July 1992 on the protection of geographical and designations of origin for agricultural products and foodstuffs.

Council Regulation (EEC) No. 2082/92 of 14 July 1992 on certificates of specific character for agricultural products and foodstuffs.

Crouse, J. D., Busboom, J. R., Field, R. A., \& Ferrel, C. L. (1981). The effect of breed, diet, sex, location and slaughter weight on lamb growth, carcass composition and meat flavour. Journal of Animal Science, 53(2), 376-386.

Crouse, J. D., Ferrell, C. L., Field, R. A., Busboom, J. R., \& Miller, G. J. (1982). The relationship of fatty acid composition and carcass characteristics to meat flavour in lamb. Journal of Food Quality, 5, 203-269.

Devine, C. E., Graafhuis, P. H., Muir, P. D., \& Chrystall, B. B. (1993). The effect of growth rate and ultimate $\mathrm{pH}$ on meat quality of lambs. Meat Science, 35, 63-77.

Dransfield, E., Nute, G. R., Hogg, B. W., \& Walters, B. R. (1990). Carcass and eating quality of ram, castrated ram and ewe lambs. Animal Production, 50, 291-299.

Ellis, M., Webster, B. C., \& Brown, I. (1997). The influence of terminal sire breed on carcass composition and eating quality of crossbred lambs. Animal Science, 64, 77-86.

Fisher, A. V., Enser, M., Richardson, R. I., Wood, J. D., Nute, G. R., Kurt, E., Sinclair, L. A., \& Wilkonson, R. G. (1999). Fatty acid composition and eating quality of lambs types derived from four diverse breed $\times$ production systems. Meat Science, 55, 141-147.

Fogarty, N. M., Hopkins, D. L., \& Vande Ven, R. (2000). Lamb production from diverse genotypes. 2. Carcass characteristics. Animal Science, 70, 147-156.

Hoffman, L. C., Muller, M., Cloete, S. W. P., \& Schmidt, D. (2003). Comparison of six crossbred lamb types: Sensory, physical and nutritional meat quality characteristics. Meat Science, 65 , 1265-1274.

Hopkins, D. L. (1993). Slite lamb and processing industry. Final report project DAN.071. Sydney, Australia: Meat Research Corporation.

Hopkins, D. L., Ferrier, G. R., Channon, H. A., \& MacDonald, B. (1995). Assessment of lamb meat quality in Sydney and Melbourne. Proceeding of the New Zealand Society of Animal Production, 55, 114-116. 
Hopkins, D. L., \& Fogarty, N. M. (1998). Diverse lamb genotype-2. Meat $\mathrm{pH}$, colour and tenderness. Meat Science, 49, 477-488.

Jeremiah, L. E., Tong, A. K. W., \& Gibson, L. L. (1998). The influence of lamb chronological age, slaughter weight, and gender. Flavor and texture profiles. Food Research International, 31(3), 227-242.

NP ISO 8586-1 (2001). Norma Portuguesa. Análise sensorial. Guia geral para a selecção treino e controlo dos provadores. Parte 1: Provadores qualificados.

Purchas, R. W., Silva Sobrinho, A. G., Garrick, D. J., \& Lowe, K. I. (2002). Effects of age at slaughter and sire genotype on fatness, muscularity, and the quality of meat from ram lambs born to Romney ewes. New Zealand of Agricultural Research, 45, $77-86$.

Rødbotten, M., Kubbeød, E., Lea, P., \& Ueland, Ø. (2004). A sensory map of the meat universe. Sensory profile of meat from 15 species. Meat Science, 68, 137-144.

Safari, E., Fogarty, N. M., Ferrier, G. R., Hopkins, L. D., \& Gilmour, A. (2001). Diverse lamb genotypes. 3. Eating quality and the relationship between its objective measurement and sensory assessment. Meat Science, 57, 153-159.

Sañudo, C., Campo, M. M., Sierra, I., María, G. A., Olleta, J. L., \& Santolaria, P. (1997). Breed effect on carcass and meat quality of suckling lambs. Meat Science, 46, 357-365.

Sañudo, C., Santolaria, P., María, G. A., Osorio, M., \& Sierra, I. (1996). Influence of carcass weight on instrumental and sensory lamb meat quality in intensive production systems. Meat Science, 42, 195-202.

Santos Silva, J., Mendes, I. A., \& Bessa, R. J. B. (2002). The effect of genotype, feeding system and slaughter weight on the quality of light lambs. 1. Growth, carcass composition and meat quality. Livestock Production Science, 76, 17-25.

SAS (2004). SAS User's Guide Statistics. Cary, NC: SAS Inst., Inc.

Schönfeldt, H. C., Naudé, R. T., Bok, W., Van Heerden, S. M., \& Sowden, L. (1993). Cooking and juiciness-related quality characteristics of goat and sheep meat. Meat Science, 34, 381-394.

Teixeira, A. (1984). Avaliação das carcaças de borregos do grupo étnico Churro Galego Bragançano e seu cruzamento com a raça Milchschaf. Relatório de estágio do curso de Engenharia Zootécnica da UTAD-Vila Real.

Vergara, H., Molina, A., \& Gallego, L. (1999). Influence of sex and slaughter weight on carcass and meat quality in light lambs produced in intensive systems. Meat Science, 52, 221-226.

Vergara, H., \& Gallego, L. (1999). Effect of type of suckling and length of lactation period on carcass and meat quality in intensive production systems. Meat Science, 53, 211-215.

Warriss, P. D. (2000). Meat science. An introduction text. Wallingford, Oxon, UK: CABI Publishing. CAB International, 310pp.

Young, O. A., Reid, D. H., \& Scales, G. H. (1993). Effect of breed and ultimate $\mathrm{pH}$ on the odour and flavour of sheep meat. New Zealand Journal of Agricultural Research, 36, 363-370. 